\title{
Designing a Low-Carbon Building via LCB Method 3.0, Case Study: An Educational Building in Tehran
}

\author{
Sami Saleki and Shooka Khoshbakht Bahramani
}

\begin{abstract}
Published online: 25 January 2019
To cite this article: Sami Saleki and Shooka Khoshbakht Bahramani (2018). Designing a low-carbon building via LCB Method 3.0, case study: An educational building in Tehran. Journal of Construction in Developing Countries, 23(2): 129-150. https://doi.org/10.21315/jcdc2018.23.2.8.
\end{abstract}

To link to this article: https://doi.org/10.21315/jcdc2018.23.2.8

\begin{abstract}
Air pollution and its damage have caused growth of concerns in human societies in the last decades. Nowadays, environmental issues are being discussed more than ever and sometimes it leads to solutions and methods to improve current situations. One of the methods is introduced in 2009 as Low-Carbon Building (LCB) Method. This method considers reduction of emissions in building during its whole lifetime. In this study, an educational building is designed with the purpose of considerable reduction in greenhouse gas (GHG) emissions. This building is investigated in different stages and eventually, the amount of carbon emissions in the building's lifetime is estimated by LCB Method 3.0 which is built on Publicly Available Specification (PAS) 2050. After estimation, it is determined that the project building, according to low-carbon buildings classification, can be ranked in Class C (good). This study also discusses effective strategies which lead to low-carbon buildings.
\end{abstract}

Keywords: GHG emissions, Low-Carbon Building (LCB) Method, LCB Method 3.0, PAS 2050, Low-carbon buildings

\section{INTRODUCTION}

Human society and the environment interact with each other. Human impacts on the environment refer to the impacts of human activities on biophysical environments, biodiversity and other resources (Han, 2012). Those activities (such as burning fossil fuels and deforestation) are responsible for the release of considerable amount of greenhouse gas (GHG) in the atmosphere which has the property of trapping solar heat. Climate model projections indicate that global surface temperature will likely rise $1.1^{\circ} \mathrm{C}$ to $6.4^{\circ} \mathrm{C}$ during the $21 \mathrm{st}$ century. This elevation in temperature causes "changes" to the average weather of regions or the earth as a whole "climate change" (Fabre, 2009). The built environment is one clear example of GHG emissions, so buildings produce considerable impact on the environment (United Nations Environment Programme, 2009). For instance, in the Tehran region, due to the very high energy consumption, carbon dioxide $\left(\mathrm{CO}_{2}\right)$ emissions are also very high, with the residential and commercial buildings making up the largest share of $41 \%$ by 2008 (Nasrollahi, 2013). Therefore, the idea of low-carbon buildings could be a solution to reduce the excessive GHG emissions in Tehran. 
Low-carbon building is a building which has been engineered to release significantly less GHG than a regular building over its lifetime (Ambapkar, 2015). Life Cycle Assessment (LCA) tools are needed in order to calculate GHG emissions from buildings. Between available tools, Low-Carbon Building (LCB) Method is used in this study. Further, this study introduces the concept of "low-carbon" buildings and LCB Method. Therefore, this paper is focused on following issues:

1. Estimating buildings lifetime GHG emissions and emissions reduction performance.

2. Low-carbon buildings design strategies and criteria which should be employed to reduce GHG emissions.

These issues are discussed and investigated with a case study and estimations are based on a LCB Method 3.0 (third edition).

\section{LIFE CYCLE ASSESSMENT (LCA)}

LCA is a technique to assess environmental impacts associated with all stages of a product's life (from raw material extraction through material processing, manufacture, distribution, use, repair and maintenance, disposal or recycling) (Sanders and Wood, 2014). In recent years, LCA software tools have become increasingly important. Today a large number of LCA programs are available. The foremost - and for the potential user also often prohibitive - property of a software tool is the price. The price of an LCA software tool can vary between several thousand euros and free of charge. Some tools offer a wider range of features than others. Some are focused on a specific field of LCA, e.g. LCA in waste management (Unger, Beigl and Wassermann, 2004).

Different groups of LCA software users can be distinguished. The first group includes scientists and researchers. The users in this group make high demands on LCA software tools: they need a flexible software tool that enables them to model "common" often-modelled scenarios as well as scenarios that diverge from the standard. Also the tool should support modelling of complex process chains. Industry, on the other hand, uses LCA software to improve its environmental performance, for process optimisation and product development. The users want "ready to-use" software, where many of the specifications are already pre-set with only a few parameters needing to be determined. Also decision makers use LCA to compare different solution options and hence also LCA software tools. Decision makers generally want an easy-to-understand presentation of the results in terms of which option is the best (Unger, Beigl and Wassermann, 2004).

This study is focused on a building industry. Table 1 includes some of existing building industry LCA tools. 
Table 1. LCA Tools in Building Industry

\begin{tabular}{|c|c|c|c|c|}
\hline Tool Name & $\begin{array}{l}\text { Supports } \\
\text { Full LCA }\end{array}$ & $\begin{array}{l}\text { LCA Scope } \\
\text { Addressed, } \\
\text { A-D* }\end{array}$ & Free? & Description \\
\hline $\begin{array}{l}\text { Athena } \\
\text { EcoCalculator }\end{array}$ & No & $A, B, C$ & Yes & $\begin{array}{l}\text { This tool is useful for a quick analysis } \\
\text { to compare the life cycle impacts } \\
\text { of primary elements of building } \\
\text { construction. }\end{array}$ \\
\hline $\begin{array}{l}\text { Athena Impact } \\
\text { Estimator }\end{array}$ & No & $A, B, C$ & Yes & $\begin{array}{l}\text { The Athena Impact Estimator is a } \\
\text { detailed tool for evaluating multiple or } \\
\text { individual material assemblies. }\end{array}$ \\
\hline BEES & Yes & $A, B, C, D$ & Yes & $\begin{array}{l}\text { The BEES software brings to your } \\
\text { fingertips a powerful technique } \\
\text { for selecting cost-effective, } \\
\text { environmentally-preferable building } \\
\text { products. }\end{array}$ \\
\hline Boustead Model & Yes & $A, B, C, D$ & No & $\begin{array}{l}\text { The Boustead Model is a self-contained } \\
\text { database and software application, } \\
\text { which enables the user to construct } \\
\text { full lifecycle inventories for virtually } \\
\text { any process situated anywhere in the } \\
\text { world. }\end{array}$ \\
\hline $\begin{array}{l}\text { Build Carbon } \\
\text { Neutral }\end{array}$ & No & A & Yes & $\begin{array}{l}\text { The Build Carbon Neutral Calculator is } \\
\text { a simple to use, online calculator that } \\
\text { requires the user to input data into only } \\
\text { nine fields. }\end{array}$ \\
\hline Eco-Bat & N/A & N/A & No & $\begin{array}{l}\text { Eco-Bat offers the possibility to quickly } \\
\text { perform the life cycle impacts analysis } \\
\text { of a building. This tool is specially } \\
\text { designed to be used during the } \\
\text { conception phase. }\end{array}$ \\
\hline Envest 2 & No & $A, B, C$ & No & $\begin{array}{l}\text { Envest } 2 \text { is an online tool that allows the } \\
\text { user to model the environmental and } \\
\text { whole life costing impacts through the } \\
\text { construction and operation of a whole } \\
\text { building over a specified time period. }\end{array}$ \\
\hline Green Footstep & No & $A, B$ & Yes & $\begin{array}{l}\text { Green Footstep accounts for carbon } \\
\text { emissions three ways: } \\
\text { Site development, construction, and } \\
\text { building operations. }\end{array}$ \\
\hline $\begin{array}{l}\text { Integrated } \\
\text { Environmental } \\
\text { Solution (IES) }\end{array}$ & Yes & $A, B, C, D$ & No & $\begin{array}{l}\text { Integrated Material Profile And } \\
\text { Costing Tool (IMPACT) allows } \\
\text { construction professionals to measure } \\
\text { the embodied environmental impact } \\
\text { and life cycle cost performance of } \\
\text { buildings. IMPACT is being developed } \\
\text { by a consortium led by BRe Global } \\
\text { and IES. }\end{array}$ \\
\hline
\end{tabular}


Table 1. (continued)

\begin{tabular}{|c|c|c|c|c|}
\hline Tool Name & $\begin{array}{l}\text { Supports } \\
\text { Full LCA }\end{array}$ & $\begin{array}{c}\text { LCA Scope } \\
\text { Addressed, } \\
\text { A-D* }\end{array}$ & Free? & Description \\
\hline $\begin{array}{l}\text { LCA in Sustainable } \\
\text { Architecture (LISA) }\end{array}$ & Yes & $A, B, C, D$ & Yes & $\begin{array}{l}\text { LISA is an Australian tool that was } \\
\text { developed "in response to requests by } \\
\text { architects and industry professionals } \\
\text { for a simplified LCA tool to assist in } \\
\text { green design". }\end{array}$ \\
\hline $\begin{array}{l}\text { LEGEP } \\
\text { (Lebenszyklus- } \\
\text { Gebäude-Planung: } \\
\text { A German } \\
\text { abbreviation for }\end{array}$ & No & $A, B, C$ & No & $\begin{array}{l}\text { LEGEP is a tool for integrated life cycle } \\
\text { analysis. It supports the planning teams } \\
\text { in the design and construction of new } \\
\text { and existing buildings or building } \\
\text { products. }\end{array}$ \\
\hline
\end{tabular}

life cycle-building-

design)

LCB Method

Yes

$A, B, C, D \quad$ Yes

LCB Method is a "simplified" methodology for estimating GHG emissions resulting from a building's construction. It is a calculating spreadsheet that builds emission data for the construction phase, reuse/ deconstruction phase and renovation. product and process LCA tool. It has a limited amount of data that can be used for buildings; mostly this would be on a materials level.

The Environmental

No A, B, C Yes

TEAM is a professional tool for evaluating the life cycle environmental Assessment and and cost profiles of products and Management technologies.

Note: *A: Production/manufacturing and construction stages (cradle to gate); B: Use stage; C: End of life stage; D: Reuse, recovery and recycling stage.

Source: Lehtinen et al. (2011) and Simonen et al. (2012)

LCB Method is chosen among these tools. LCB Method is free, simple, relatively accurate (Fabre, 2009) and supports full LCA (Wang, Wu and Zhang, 2016). This tool is built and promoted for architects, engineers, construction managers, owners, or anyone interested in low carbon buildings across the design and construction industry. It is built to handle all building types, as well as, residential, commercial, industrial, interior design and infrastructure project types (Simonen et al., 2012). 


\section{THE CONCEPT OF LOW-CARBON BUIDLINGS}

Low carbon content building is one of the techniques of sustainable development in which attempt is made for reducing emissions by using low carbon emission materials and low carbon emission techniques (Landage, 2013). A building emits GHG during its whole lifetime, therefore engineering a low-carbon building is a progress that concerns all stages of the building life.

\section{Low-Carbon Building Classification}

The LCB Method 2009 proposes LCB classification as illustrated in Figure 1.

\section{Building GHG Emissions \\ Reduction (\%)*}

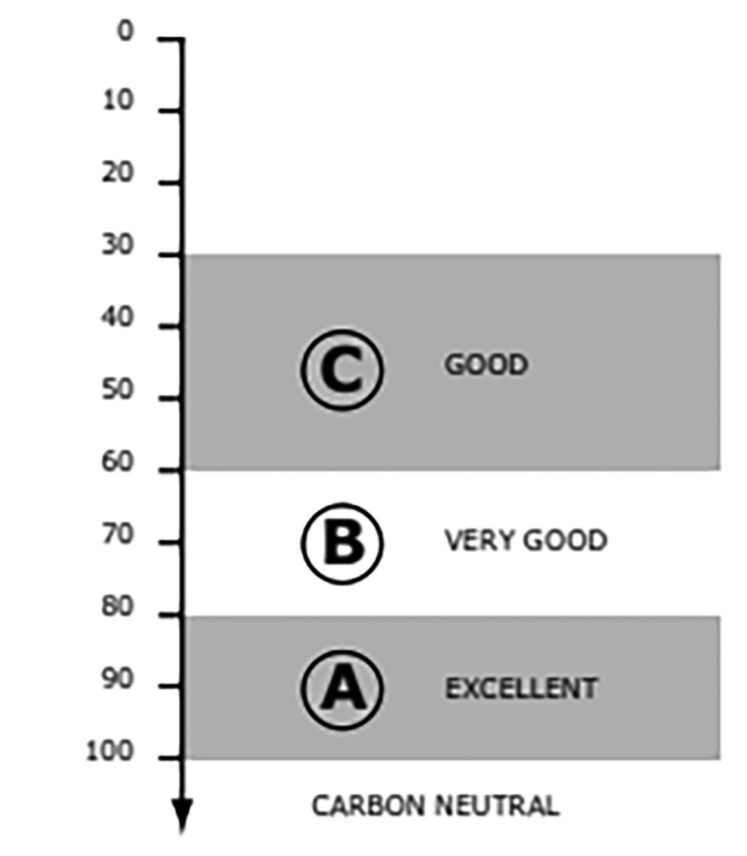

- Compared to Baseline

Figure 1. Low-Carbon Buildings Proposed Classification Source: Fabre (2009)

\section{Key Definitions}

1. Baseline building: the building which would most likely has been constructed if no particular GHG emissions reduction strategies had been considered (Fabre, 2009).

2. Project building: the building which is designed by project team with GHG emissions reduction strategies (Fabre, 2009). 


\section{LOW-CARBON BUILDINGS: A STEP BY STEP APPROACH}

\section{LCB Method (First Edition, 2009)}

The LCB Method recommends the step by step approach (see Figure 2) for achieving the desired emissions reduction performance.

The project team should focus on phases 1 to 3 of the process as a priority (Fabre, 2009). Since estimation for the case study is based on the third edition of LCB Method, here only the most significant factors of the first edition are introduced.

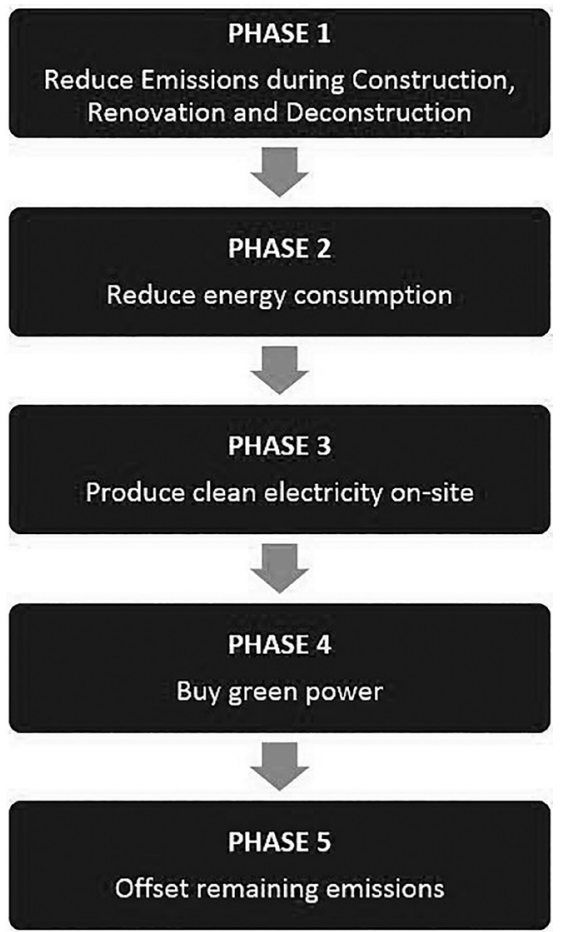

Figure 2. LCB Method: A Step by Step Approach (First Edition) Source: Fabre (2009)

\section{Phase 2 from the first edition: Reduce energy consumption}

After construction, a building has an "operational life" of approximately 50 years. GHG are emitted as a consequence of the energy used by the building for lighting, artificial heating and cooling, etc. Most of the time, this energy is generated by the burning of fossil fuels such as coal, oil, gas, etc. (Fabre, 2009). There are consequently three ways to reduce the emissions of a building during operation:

1. To install energy-efficient systems.

2. To produce on-site or purchase renewable energy, in particular clean electricity.

3. To use passive solar building strategies in order to reduce energy consumption. 
Moreover, it should be mentioned that medium to heavyweight construction is likely to provide more potential for achieving higher levels of indoor comfort and reduced lifecycle $\mathrm{CO}_{2}$ emissions (Hacker et al., 2008).

\section{Phase 3 from the first edition: Produce clean electricity on-site}

Renewable energy sources (such as wind, sunlight, biomass.) can provide part of the energy, to in theory all the energy of a building. If embodied emissions are excluded, the electricity produced from renewable energy is considered to be emissions free, and the associated emission factor is:

$$
\text { EFrenewable }=0 \mathrm{~g} \mathrm{CO}_{2}-\mathrm{e} / \mathrm{kWh} \text { (Fabre, 2009). }
$$

\section{LCB Method 3.0 (Third Edition, 2011)}

The life cycle GHG emissions/removals of the project building shall be estimated by the step-by-step approach as shown in Figure 3.

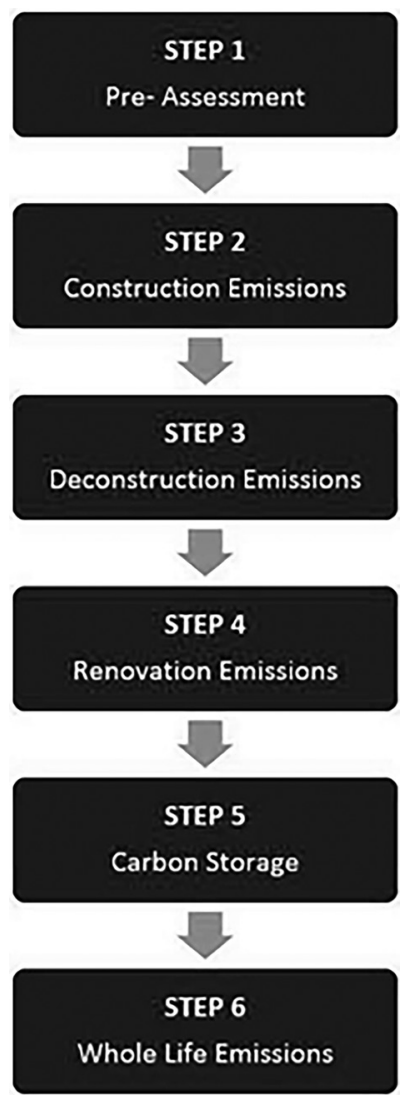

Figure 3. LCB Method: A Step by Step Approach (Third Edition) Source: Fabre (2012) 


\section{Step 1: Pre-assessment}

Estimate the contribution of each material to the life cycle emissions of the building prior to the detailed assessment by doing the pre-assessment. The pre-assessment is intended to identify the sources of emissions that shall be included in the assessment (Fabre, 2012). This step can be estimated by www.shapedearth.com.

\section{Step 2: Construction emissions}

The construction sector is the largest global consumer of materials (Giesekam et al., 2016) and over half the embodied carbon in construction is associated with the consumption of materials (Giesekam et al., 2014). Generally, GHG are emitted during five phases in construction (see Figure 4). Emissions associated with the building construction are calculated as shown in Equations 1, 2 and 3 (Fabre, 2012).

$$
\begin{array}{ll}
\left.E_{C C}={ }_{\text {mat }, i}+E_{\text {trans mat }, i}\right) & \text { Eq. } 1 \\
E_{\text {mat }, i}=W_{\text {mat }, i} \times E F_{\text {mat }, i} & \text { Eq. } 2 \\
E_{\text {trans mat }, i}=W_{\text {mat }, i} \times d_{\text {trans mat }, i} \times E F_{\text {trans mat }, i} & \text { Eq. } 3
\end{array}
$$

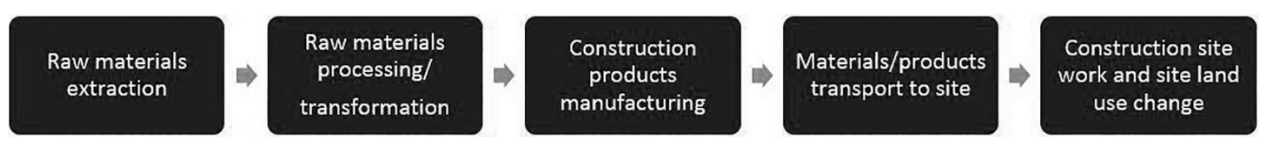

Figure 4. Emissions of GHG during Construction Phase

\section{Example for wall's material}

Wall's material for the project building is considered to be light expanded clay aggregate (LECA) blocks and for a baseline building is clay brick.

LECA block for the project building:

$W_{\text {mat }}=605,858 \mathrm{~kg}, E F_{\text {mat }}=0.249 \mathrm{kgCO}_{2} \mathrm{e} / \mathrm{kg}, d_{\text {trans mat }}=50 \mathrm{~km}, E F_{\text {trans mat }}$ $=0.000125 \mathrm{kgCO} 2 \mathrm{e} / \mathrm{kg} \cdot \mathrm{km}$

Notes:

1. If the vehicle is empty on its return, multiply its emission factor by 1.8 .

2. if the quantity of materials shown on the drawing is used, account for construction waste by multiply this quantity by 1.09 .

$$
\begin{aligned}
& E_{\text {mat }, i}=605,858 \times 1.09 \times 0.249 \approx 164,435.9 \mathrm{kgCO}_{2} \mathrm{e} \\
& E_{\text {trans mat }, i}=605,858 \times 1.09 \times 50 \times 0.000125 \times 1.8 \approx 7,429.3 \mathrm{kgCO}_{2} \mathrm{e} \\
& E_{C C}=164,435.9+7429.3=171,865.2 \mathrm{kgCO}_{2} \mathrm{e}
\end{aligned}
$$


Clay brick for a baseline building:

$W_{\text {mat }}=1,203,889 \mathrm{~kg}, E F_{\text {mat }}=0.48 \mathrm{kgCO}_{2} \mathrm{e} / \mathrm{kg}, d_{\text {trans mat }}=20 \mathrm{~km}, E F_{\text {trans mat }}$ $=0.000125 \mathrm{kgCO}{ }_{2} \mathrm{e} / \mathrm{kg} \cdot \mathrm{km}$

$$
\begin{aligned}
& E_{\text {mat }, i}=1,203,889 \times 1.09 \times 0.48 \approx 629874.7 \mathrm{kgCO}_{2} \mathrm{e} \\
& E_{\text {trans mat }, i}=1,203,889 \times 1.09 \times 20 \times 0.000125 \times 1.8 \approx 5,905 \mathrm{kgCO}_{2} \mathrm{e} \\
& E_{C C}=629,874.7+5,905=635,779.7 \mathrm{kgCO}_{2} \mathrm{e}
\end{aligned}
$$

Results show that construction emissions for walls from LECA blocks is about $73 \%$ lesser than clay bricks.

\section{Step 3: Deconstruction emissions}

During deconstruction, materials constituting the building become waste. There are three main waste treatment methods: (1) disposal in landfills, (2) incineration and (3) recycling (Fabre, 2009). GHG are emitted during three phases in deconstruction (see Figure 5). Emissions associated with the building deconstruction are calculated as shown in Equations 4, 5 and 6.

$$
\begin{array}{ll}
\left.E_{D C}={ }_{\text {waste }, i}+E_{\text {trans waste }, i}\right) & \text { Eq. } 4 \\
E_{\text {waste }, i}=W_{\text {mat }, i} \times\left(\delta_{\text {land }, i} \times E F_{\text {land }, i}+\delta_{\text {inc }, i} \times E F_{\text {inc }, i}\right) & \text { Eq. } 5 \\
E_{\text {trans waste }, i}=W_{\text {mat }, i} \times\left(\delta_{\text {land }, i}+\delta_{\text {inc }, i}\right) \times d_{\text {trans waste }} \times E F_{\text {trans waste }} & \text { Eq. } 6
\end{array}
$$

\section{Step 4: Renovation emissions}

The use phase of the building spans from the end of its construction to its deconstruction. The emissions anticipated to occur during this phase are the emissions associated with the replacement of the materials constituting the building (Fabre, 2012). GHG are emitted during several phases in building renovation (see Figure 6). Emissions associated with the building renovation are calculated as shown in Equations 7 and 8 (Fabre, 2012).

$$
\begin{array}{ll}
\left.\left.E_{R C}={ }_{\text {mat }, i}+E_{\text {trans mat }, i}+E_{\text {waste }, i}+E_{\text {trans waste, } i}\right] \times N_{i}\right) & \text { Eq. } 7 \\
\text { if } L_{i}<L, N_{i}=\left|L / L_{i}\right|, \text { if } L_{i} \geq L, N_{i}=0 & \text { Eq. } 8
\end{array}
$$
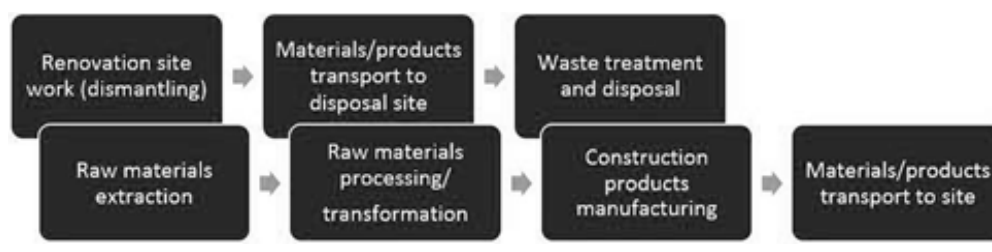

Figure 6. Emissions of GHG during Renovation Phase 


\section{Step 5: Carbon storage}

Carbon storage may arise when materials containing biogenic carbon (e.g., wood) or materials having the ability to take up atmospheric carbon over their life cycle (e.g., cement) are used on the project (Fabre, 2012). Equation 9 illustrates how to calculated carbon storage (Fabre, 2012).

$$
\left.R_{C S}=(-1) \times{ }_{\text {mat }, i} \times\left[\delta_{\text {conc }, i} \times K_{\text {conc }}+\delta_{\text {wood }, i} \times K_{\text {wood }}\right] \times\left[1-\delta_{\text {rec }, i}\right] \times\left[N_{i}+1\right]\right) \quad \text { Eq. } 9
$$

\section{Step 6: Whole life emissions}

Total emissions of the building are calculated as illustrated in Equation 10 (Fabre, 2012).

$$
E_{W L C}=E_{C C}+E_{D C}+E_{R C}+R_{C S}
$$

Emissions from site activities (site work) and site land use change for construction, deconstruction and renovation should be estimated as below. Estimation of the emissions from construction site work and land use change as shown in Table 2 and Table 3.

Table 2. Default Emission Factors for Construction Site Work

\begin{tabular}{lc}
\hline Type of Project & Emission Factor $\mathrm{kgCO}_{2} \mathrm{e} / \mathrm{m}^{2}$ GFA \\
\hline Residential & 20 \\
Non-residential & 12 \\
\hline
\end{tabular}

Source: Fabre (2012)

Note: GFA = Gross Floor Area

Table 3. Default Emission Factors for Site Land Use Change

\begin{tabular}{lc}
\hline Land Use Change & Emission Factor $\mathrm{kgCO}_{2} \mathrm{e} / \mathrm{m}^{2}$ \\
\hline Forestland $<->$ Hardscape & \pm 30 \\
Forestland $<->$ Grassland & \pm 26 \\
Grassland $<->$ Hardscape & \pm 4 \\
\hline
\end{tabular}

Note: Land use change may occur on-site as a consequence of the construction activities. Multiply the surface area of the disturbed land by the appropriate emission factor from the table (+ve if loss of biomass; -ve if gain of biomass).

Source: Fabre (2012)

The emissions from deconstruction site work are estimated as indicated in Equation 11 while for the emissions from renovation site work, the estimation is as indicated in Equation 12 (Fabre, 2012).

$$
\begin{aligned}
& \text { GHG emissions }=E_{\text {site work }} / 2.5 \\
& \text { GHG emissions }=E_{\text {site work }} \times L / 75
\end{aligned}
$$$$
\text { Eq. } 11
$$ 


\section{CASE STUDY}

Air pollution and its consequences (such as economic pollution) have caused irreparable damage especially in industrial cities of Iran, like Tehran (Karimzadegan et al., 2008). energy consumption per capita in domestic and commercial sector is 1.9 times more than the global average also using renewable energy sources are lesser than global average (Iran's Energy Balance 2012 [2013]). Therefore, it seems a method which can focus on both energy and GHG emissions issues are vital.

Project site is located in Jashnvareh Blvd, sixth zone of district four, Tehran. District four has the second highest number of industrial services unites in Tehran city. This could help to reduce materials transport emissions. The site is located near to taxi station, bus stop and subway station which provides easy access to the site.

\section{Estimating Building Lifetime GHG Emissions by LCB Method Version 3.0}

\section{Step 1: Pre-assessment}

On this stage, emissions are estimated in www.shapedearth.com (Fabre, 2011) and some data like emission factors are available from www.lcbmethod.com/appendix (Fabre, 2014).

The construction industry requires the extraction of vast quantities of materials and this, in turn, results in the consumption of energy resources and the release of deleterious pollutant emissions to the biosphere (Hammond and Jones, 2008). To minimise emissions, it is essential to device technologies to produce building materials and products with minimum amount of energy expenditure (Reddy, 2009). Therefore, selecting materials with lower embodied carbon such as stabilised mud blocks, compacted fly ash blocks, rammed earth walls and blended cements can be used in low-carbon projects. This study is tried to use technology and materials which are common and available for construction in Iran in order to verify that lowcarbon buildings could be built by common materials and technologies. Table 4 shows materials consist in the project building.

Total emissions for the project building are estimated about 55,567 $\mathrm{kgCO}_{2} \mathrm{e}$. Table 5 shows materials consist in a baseline building with a total emission for a baseline building is estimated about $89,568 \mathrm{kgCO}_{2} \mathrm{e}$. On the other notes, Tables 6 to 10 are required in the next steps (Step 2 to 5) for more accurate estimations and actual distances mostly used for this project. 


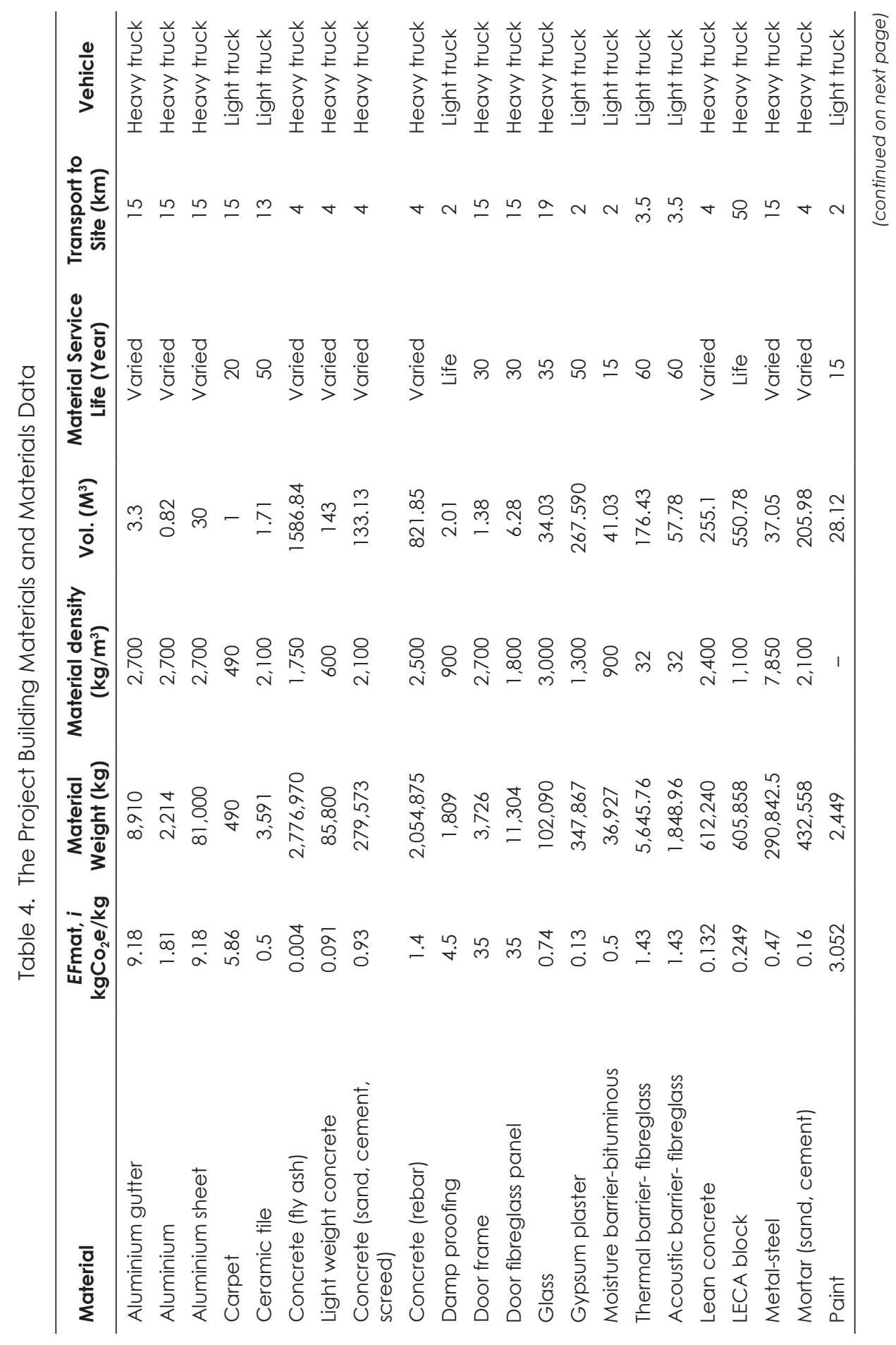



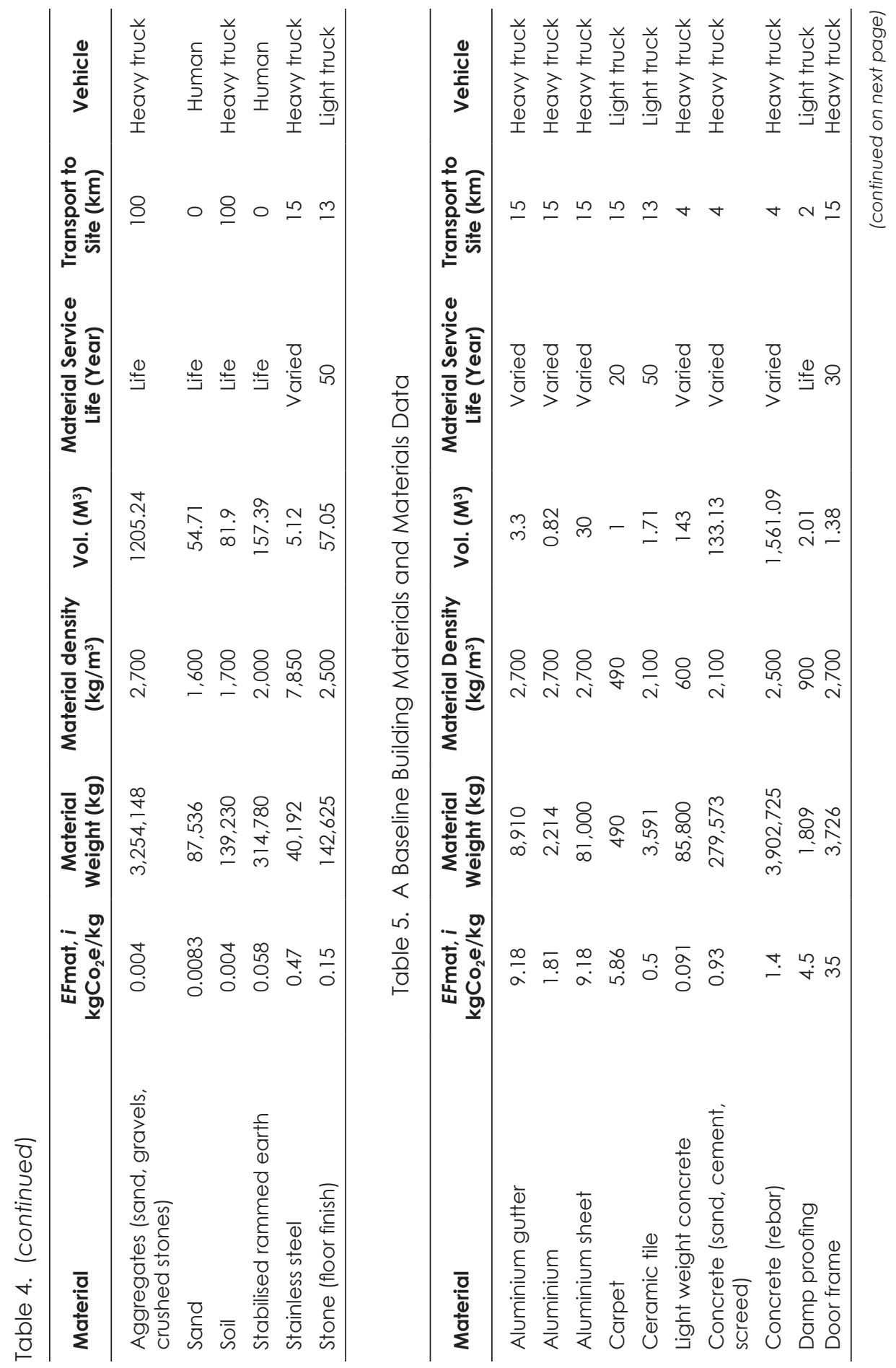


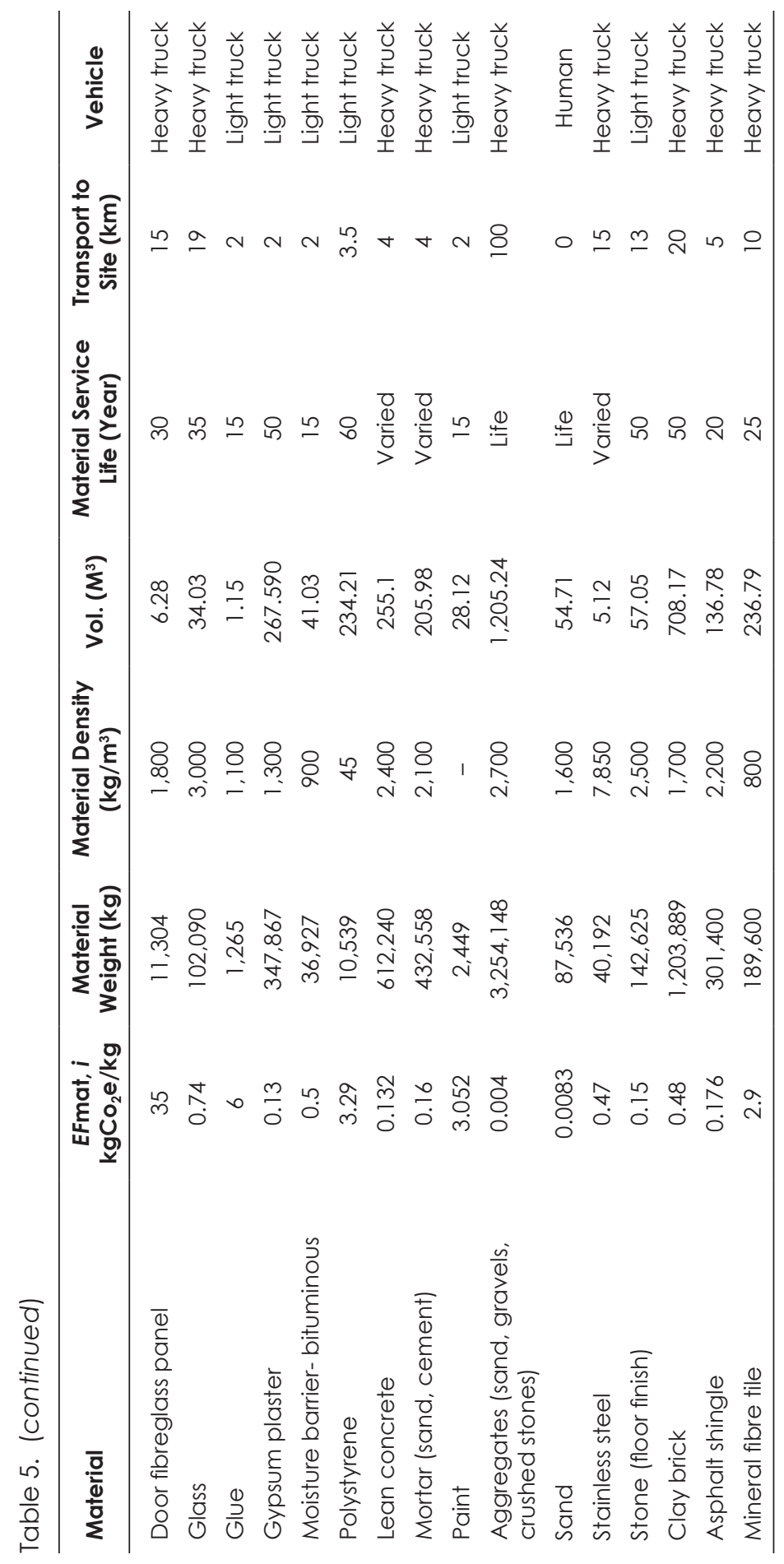


Table 6. Default Emission Factor of the Vehicle Used for Materials Transportation

\begin{tabular}{lc}
\hline Vehicle & $\mathbf{E F}_{\text {trans }} \mathbf{m a t}(\mathbf{g C O} \mathbf{e}$ /ton.km) \\
\hline Human and animal transportation & 0 \\
Truck-light-duty truck (up to 3.5 tons gross weight) & 590 \\
Truck-medium- and heavy-duty truck (3.5 tons gross & 125 \\
weight or more) & 30 \\
Rail & 30 \\
Barge & 5 \\
Boat-bulk carrier & 15 \\
Boat-containers & 1,350 \\
Airplane & \\
\hline
\end{tabular}

Source: Fabre (2012)

Table 7. Default Proportion (wt \%) of Each Materials Sent to Landfill ( $\Delta$ land), Incinerator $(\Delta \mathrm{inc})$ and Recycling $(\Delta \mathrm{rec})$

\begin{tabular}{lccc}
\hline Material & $\boldsymbol{\delta}_{\text {Iand }}(\boldsymbol{\%})$ & $\boldsymbol{\delta}_{\text {inc }}(\boldsymbol{\%})$ & $\boldsymbol{\delta}_{\text {rec }}(\boldsymbol{\%})$ \\
\hline Concrete & 45 & 0 & 55 \\
Other mineral materials (non-metallic) & 45 & 0 & 55 \\
Wood & 40 & 35 & 25 \\
Metal & 25 & 0 & 75 \\
Plastics & 70 & 20 & 10 \\
Others, mixed & 100 & 0 & 0 \\
\hline
\end{tabular}

Source: Fabre (2012)

Table 8. Default Transportation Emissions of Each Material from Gate (Factory) to Site

\begin{tabular}{lc}
\hline Material & $\boldsymbol{d}_{\text {trans mat }}(\mathbf{k m})$ \\
\hline Concrete & 10 \\
Other mineral materials (non-metallic) & 100 \\
Wood & 350 \\
Metal & 500 \\
Plastics & 1,050 \\
Others, mixed & 1,500 \\
\hline
\end{tabular}

Source: Fabre (2012) 
Table 9. Default Emission Factor of Materials in Landfill and in Incinerator

\begin{tabular}{lcc}
\hline Material & $\mathbf{E F}_{\text {land }}\left(\mathbf{k g C O}_{2} \mathbf{e} /\right.$ ton $)$ & $\mathbf{E F}_{\text {inc }}\left(\mathbf{k g C O}_{2} \mathbf{e} /\right.$ ton $)$ \\
\hline Concrete & 0 & 0 \\
Other mineral materials (non-metallic) & 0 & 0 \\
Wood & 2,150 & 1,560 \\
Metal & 0 & 0 \\
Plastics & 0 & 2,800 \\
\hline
\end{tabular}

Source: Fabre (2012)

Table 10. Default Transportation Distance of Materials Sent to Landfill, Incinerator and Recycling Plant

\begin{tabular}{lc}
\hline Destination & Distance (km) \\
\hline Landfill & 100 \\
Incineration Plant & 100 \\
Recycling Plant & 100 \\
\hline Source: Fabre (2009) &
\end{tabular}

\section{Step 2: Construction emission}

Construction emissions for the baseline and the project buildings are calculated as shown in Table 11.

Table 11. Construction Emissions for the Baseline and the Project Buildings

\begin{tabular}{|c|c|c|c|}
\hline \multicolumn{2}{|c|}{ Project Building } & \multicolumn{2}{|c|}{ Baseline Building } \\
\hline Material & Result $\left(\mathrm{kgCO}_{2} \mathrm{e}\right)$ & Material & Result $\left(\mathrm{kgCO}_{2} \mathrm{e}\right)$ \\
\hline Aluminium gutter & $89,187.9$ & Aluminium gutter & $89,187.9$ \\
\hline Aluminium & $4,370.7$ & Aluminium & $4,370.7$ \\
\hline Aluminium sheet & $810,800.1$ & Aluminium sheet & $810,800.1$ \\
\hline Carpet & $3,138.3$ & Asphalt shingle & 58,190 \\
\hline Ceramic tile & 2,011 & Carpet & $3,138.3$ \\
\hline Concrete (fly ash) & $14,831.7$ & Ceramic tile & 2,011 \\
\hline Light weight concrete & $8,594.6$ & Clay brick & $635,779.7$ \\
\hline $\begin{array}{l}\text { Concrete (sand, cement, } \\
\text { screed) }\end{array}$ & $283,677.3$ & Light weight concrete & $8,594.6$ \\
\hline Concrete (rebar) & $3,137,755$ & $\begin{array}{l}\text { Concrete (sand, } \\
\text { cement, screed) }\end{array}$ & $283,677.3$ \\
\hline Damp proofing & $8,877.3$ & Concrete (rebar) & $5,959,386.8$ \\
\hline Door frame & $142,159.9$ & Damp proofing & $8,877.3$ \\
\hline
\end{tabular}




\begin{tabular}{|c|c|c|c|}
\hline \multicolumn{2}{|c|}{ Project Building } & \multicolumn{2}{|c|}{ Baseline Building } \\
\hline Material & Result $\left(\mathrm{kgCO}_{2} \mathrm{e}\right)$ & Material & Result $\left(\mathrm{kgCO}_{2} \mathrm{e}\right)$ \\
\hline Door fibreglass panel & $431,289.1$ & Door frame & $142,159.9$ \\
\hline Glass & $8,2821.4$ & Door fiberglass panel & $431,289.1$ \\
\hline Gypsum plaster & 50,098 & Glass & $82,821.4$ \\
\hline $\begin{array}{l}\text { Moisture barrier } \\
\text { (bituminous) }\end{array}$ & $20,210.7$ & Glue & 8,276 \\
\hline Thermal barrier (fibreglass) & $8,826.2$ & Gypsum plaster & 50,098 \\
\hline Acoustic barrier (fibreglass) & $2,890.5$ & $\begin{array}{l}\text { Moisture barrier } \\
\text { (bituminous) }\end{array}$ & $20,210.7$ \\
\hline Lean concrete & $88,689.6$ & Lean concrete & $88,689.6$ \\
\hline LECA block & $171,865.2$ & Mortar (sand, cement) & $75,862.4$ \\
\hline Metal-steel & $150,068.5$ & Mineral fibre tile & $599,790.5$ \\
\hline Mortar (sand, cement) & $75,862.4$ & Paint & $8,152.6$ \\
\hline Paint & $8,152.6$ & polystyrene & $37,842.7$ \\
\hline Rubble & $86,901.9$ & Rubble & $86,901.9$ \\
\hline Sand & 791.9 & Sand & 791.9 \\
\hline Soil & $4,021.6$ & Stainless steel & $20,738.1$ \\
\hline Stabilised rammed earth & $19,900.4$ & Stone (floor) & $25,620.8$ \\
\hline Stainless steel & $20,738.1$ & & \\
\hline Stone (floor) & $25,620.8$ & & \\
\hline Construction site work* & 62,700 & Construction site work* & 62,700 \\
\hline site land use change & $6,378.8$ & Site land use change & $20,955.6$ \\
\hline Total construction emission & $\begin{array}{c}5,823,231.5 \\
\mathrm{kgCO}_{2} \mathrm{e}\end{array}$ & $\begin{array}{l}\text { Total construction } \\
\text { emission }\end{array}$ & $\begin{array}{l}9,626,914.9 \\
\mathrm{kgCO}_{2} \mathrm{e}\end{array}$ \\
\hline
\end{tabular}

Notes: *Area (GFA) $=5,225 \mathrm{~m}^{2}$

1. If the vehicle is empty on its return, multiply its emission factor by 1.8 .

2. If the quantity of materials shown on the drawing is used, account for construction waste by multiply this quantity by 1.09 . 


\section{Step 3: Deconstruction emissions}

Deconstruction emissions for the baseline and the project buildings are calculated as shown in Table 12.

Table 12. Deconstruction Emissions for the Baseline and the Project Building

\begin{tabular}{|c|c|c|c|}
\hline \multicolumn{2}{|c|}{ Project Building } & \multicolumn{2}{|c|}{ Baseline Building } \\
\hline Material & Result $\left(\mathrm{kgCO}_{2} \mathrm{e}\right)$ & Material & Result $\left(\mathrm{kgCO}_{2} \mathrm{e}\right)$ \\
\hline Bituminous & $22,721.1$ & Bituminous & $22,721.1$ \\
\hline Damp proofing & 1,112 & Damp proofing & 1,112 \\
\hline \multirow[t]{3}{*}{ Fibreglass } & $11,563.8$ & Expanded polystyrene (EPS) & $6,483.3$ \\
\hline & & Fibreglass & $6,954.6$ \\
\hline & & Glue & 779 \\
\hline Deconstruction site work & 25,080 & Deconstruction site work & 25,080 \\
\hline $\begin{array}{l}\text { Total deconstruction } \\
\text { emission }\end{array}$ & $60,476.9 \mathrm{kgCO}_{2} \mathrm{e}$ & $\begin{array}{l}\text { Total deconstruction } \\
\text { emission }\end{array}$ & $63,130 \mathrm{kgCO}_{2} \mathrm{e}$ \\
\hline
\end{tabular}

Note: If the vehicle is empty on its return, multiply its emission factor by 1.8 .

\section{Step 4: Renovation emissions}

Renovation emissions for the baseline and the project buildings are calculated as shown in Table 13.

Table 13. Renovation Emissions for the Baseline and the Project Building

\begin{tabular}{|c|c|c|c|}
\hline \multicolumn{2}{|c|}{ Project Building } & \multicolumn{2}{|c|}{ Baseline Building } \\
\hline Material & Result $\left(\mathrm{kgCO}_{2} \mathrm{e}\right)$ & Material & Result $\left(\mathrm{kgCO}_{2} \mathrm{e}\right)$ \\
\hline Carpet & $3,138.3$ & Carpet & $3,138.3$ \\
\hline Door frame & $142,159.9$ & Door frame & $142,159.9$ \\
\hline Door panel & $438,243.7$ & Door panel & $438,243.7$ \\
\hline $\begin{array}{l}\text { Moisture barrier } \\
\text { bituminous }\end{array}$ & $128,795.4$ & $\begin{array}{l}\text { Moisture barrier } \\
\text { bituminous }\end{array}$ & $128,795.4$ \\
\hline \multirow[t]{4}{*}{ Paint } & $24,457.5$ & Paint & $24,457.8$ \\
\hline & & Glue & 27,165 \\
\hline & & Asphalt shingle & 116,380 \\
\hline & & Mineral fibre tile & $599,790.5$ \\
\hline Renovation site work & 41,382 & Renovation site work & 41,382 \\
\hline $\begin{array}{l}\text { Total renovation } \\
\text { emission }\end{array}$ & $778,176.8 \mathrm{kgCO}_{2} \mathrm{e}$ & $\begin{array}{l}\text { Total renovation } \\
\text { emission }\end{array}$ & $1,521,512.6 \mathrm{kgCO}_{2} \mathrm{e}$ \\
\hline
\end{tabular}




\section{Step 5: Carbon storage}

Carbon storage for the baseline and the project buildings are calculated as shown in Table 14.

Table 14. Carbon Storage for the Baseline and the Project Building

\begin{tabular}{|c|c|c|c|}
\hline \multicolumn{2}{|c|}{ Project Building } & \multicolumn{2}{|c|}{ Project Building } \\
\hline Material & Result $\left(\mathrm{kgCO}_{2} \mathrm{e}\right)$ & Material & Result $\left(\mathrm{kgCO}_{2} \mathrm{e}\right)$ \\
\hline Concrete (fly ash) & $-9,534.7$ & Light weight concrete & -324 \\
\hline Light weight concrete & -324 & $\begin{array}{l}\text { Concrete (sand, cement, } \\
\text { screed) }\end{array}$ & $-1,371.2$ \\
\hline $\begin{array}{l}\text { Concrete (sand, } \\
\text { cement, screed) }\end{array}$ & $-1,371.2$ & Mortar (sand, cement) & $-2,121.6$ \\
\hline Mortar (sand, cement) & $-2,121.6$ & Concrete (rebar) & $-19,142.8$ \\
\hline Concrete (rebar) & $-10,079.1$ & Lean concrete & $-30,029.6$ \\
\hline Lean concrete & $-30,029.6$ & & \\
\hline LECA block & $-2,080.2$ & & \\
\hline Total carbon storage & $-55,540.4 \mathrm{kgCO}_{2} \mathrm{e}$ & Total carbon storage & $-52,989.2 \mathrm{kgCO}_{2} \mathrm{e}$ \\
\hline
\end{tabular}

\section{Step 6: Whole life emissions}

Whole life emissions for the project building: $6606344.8 \mathrm{kgCO}_{2} \mathrm{e}$ Whole life emissions for a baseline building: $11158568.3 \mathrm{kgCO}_{2} \mathrm{e}$

Comparison between pre-assessment and detailed assessment are shown in Table 15.

Table 15. Comparison between Pre-Assessment (Step 1) and Detailed Assessments (Step 2 To 5)

\begin{tabular}{lcccc}
\hline & $\begin{array}{c}\text { Project Building } \\
\text { Emissions } \\
\left(\mathbf{k g C O}_{2} \mathbf{e}\right)\end{array}$ & $\begin{array}{c}\text { Baseline Building } \\
\text { Emissions } \\
\left(\mathbf{k g C O}_{\mathbf{2}} \mathbf{e}\right)\end{array}$ & $\begin{array}{c}\text { Emission } \\
\text { Reduction } \\
\text { Performance }\end{array}$ & $\begin{array}{c}\text { LCB } \\
\text { Classification }\end{array}$ \\
\hline Pre-assessment results & 55,567 & 89,568 & $38 \%$ & Class C (good) \\
$\begin{array}{l}\text { Detailed assessments } \\
\text { results }\end{array}$ & $6,606,344.8$ & $11,158,568.3$ & $40.8 \%$ & Class C (good) \\
\hline
\end{tabular}

Some actions which are used in the project building to reduce emissions are: using recyclable materials, minimise site land use change, use earth material of the site (rammed earth), using durable materials and reducing transport distance by using local materials. 


\section{CONCLUSION}

Overall, the amount of emissions from pre-assessment step for the project building is $38 \%$ lesser than a baseline building. Results of the detailed assessment (step 2 to 5) justify the pre-assessment estimation, and illustrate that the project building emission is $40.8 \%$ lesser than baseline building. Therefore, according to low-carbon buildings classifications, the project building can be ranked in Class C (good).

Estimations indicate that the construction phase has the highest amount of emissions compared to other phases. As can be seen by estimations, some of the effective factors to reduce emissions are building structure and materials transportation. Some effective ways to reduce emissions from buildings are:

1. Choose recycled materials for the structure: fly ash concrete, recycled, steel, wood from well-managed forest.

2. Reduce materials/products quantities.

3. Substitute materials with the ones which have lower emission factors.

4. Reduce development area.

5. Use materials that will be recycled.

6. Reuse materials such as materials salvaged from other project.

7. Use durable materials.

8. Use low embodied carbon material such as rammed earth, straw and etc.

9. Use local materials to reduce transport emissions.

10. Reduce development area and preserve biodiversity.

11. Produce clean electricity on-site.

12. Use passive design and technologies.

It should be mentioned that some programmes like Renewable Energy Certificated (RECS) and carbon offset credits are needed to create carbon neutral buildings. Unfortunately, these programs are not available in Iran. However, using carbon reduction opportunities, as mentioned above, can be helpful to minimise emissions from building industry as much as possible. 


\section{APPENDIX}

This is a list of the abbreviated terms used throughout the article and the definitions:

\begin{tabular}{|c|c|}
\hline$d_{\text {trans mat, } i}$ & Distance gate-site for material $i$ \\
\hline$d_{\text {trans waste }}$ & Distance site-disposal \\
\hline$E_{c c}$ & Construction emissions (construction carbon) \\
\hline$E_{\mathrm{dc}}$ & Deconstruction emissions (deconstruction carbon) \\
\hline$E_{\mathrm{rc}}$ & Renovation emissions (renovation carbon) \\
\hline$E_{\text {mat }, i}$ & Cradle-to-gate emissions of material $i$ \\
\hline$E_{\text {trans mat }, i}$ & Transport emissions of material i from gate to site \\
\hline$E_{\text {trans waste, } i}$ & Transport emissions of material $i$ from site to grave \\
\hline$E_{\text {waste }, i}$ & Waste treatment emissions of material $i$ \\
\hline$E F_{\text {inc }, i}$ & Emission factor of material $i$ in incinerator \\
\hline$E F_{\text {land }, i}$ & Emission factor of material $i$ in landfill \\
\hline$E F_{\text {mat }, i}$ & Cradle-to-gate emission factor of material $i$ \\
\hline$E F_{\text {trans }}$ mat,$i$ & Emission factor of the vehicle used to transport material $i$ to site \\
\hline$E F_{\text {trans waste }}$ & Emission factor of the vehicle used to transport waste to disposal \\
\hline $\begin{array}{l}K_{\text {conc }}=0.01 \\
K_{\text {wood }}=1.56\end{array}$ & $\begin{array}{l}\mathrm{K}_{\text {conc }} \text { is the atmospheric carbon, expressed in } \mathrm{kgCO}_{2} \mathrm{e} \text {, taken up by } 1 \mathrm{~kg} \\
\text { concrete over a } 100 \text {-year period. } \\
\mathrm{K}_{\text {wood }} \text { is the carbon content, expressed in } \mathrm{kgCO}_{2} \mathrm{e} \text {, of } 1 \mathrm{~kg} \text { wood (wet } \\
\text { weight). }\end{array}$ \\
\hline L & Expected service life of the building \\
\hline$L_{i}$ & Expected service life of material $i$ \\
\hline $\mathrm{n}$ & Total number of materials included in the assessment \\
\hline$N_{i}$ & Expected number of replacement instances of material $i$ \\
\hline$W_{\text {mat }, i}$ & Weight of material $i$ \\
\hline $\boldsymbol{\delta}_{\text {conc }, i}$ & Proportion (wt \%) of concrete in material $i$ \\
\hline $\boldsymbol{\delta}_{\text {inc, } i}$ & Proportion (wt \%) of material i sent to incinerator \\
\hline $\boldsymbol{\delta}_{\text {land, } i}$ & Proportion (wt \%) of material i sent to landfill \\
\hline$\delta_{\mathrm{rec}, i}$ & Proportion (wt \%) of material i sent to recycling \\
\hline $\boldsymbol{\delta}_{\text {wood }, i}$ & Proportion (wt \%) of eligible wood in material $i$ \\
\hline
\end{tabular}

\section{REFERENCES}

Ambapkar, R. (2015). A survey on: A dive towards low carbon building. International Journal of Advanced Engineering and Research Development, 2(1): 219-223.

Fabre, G. (2014). Appendices. In G. Fabre (ed.). The Low-Carbon Buildings Method 3.0. North Carolina: Lulu Press.

. (2012). The Low-Carbon Buildings Method 3.0. North Carolina: Lulu Press. . (2011). Shaped. Available at: http://www.shapedearth.com/. (2009). Low-Carbon Building: A Method for Estimating GHG Emissions and Emissions Reduction Performance. North Carolina: Lulu Press. 
Giesekam, J., Barrett, J.R. and Taylor, P. (2016). Construction sector views on low carbon building materials. Building Research and Information, 44(4): 423-444. https://doi.org/10.1080/09613218.2016.1086872.

Giesekam, J., Barrett, J., Taylor, P. and Owen, A. (2014). The greenhouse gas emissions and mitigation options for materials used in UK construction. Energy and Buildings, 78: 202-214. https://doi.org/10.1016/j.enbuild.2014.04.035.

Hacker, J.N., De Saulles, T.P., Minson, A.J. and Holmes, M. (2008). Embodied and operational carbon dioxide emissions from housing: A case study on the effects of thermal mass and climate change. Energy and Buildings, 40(3): 375-384. https://doi.org/10.1016/j.enbuild.2007.03.005.

Hammond, G.P. and Jones, C.I. (2008). Embodied energy and carbon in construction materials. Proceedings of the Institution of Civil Engineers: Energy, 161 (2): 8798. https://doi.org/10.1680/ener.2008.161.2.87.

Han, D. (2012). Concise Environmental Engineering. London: Bookboon.

Karimzadegan, H., Rahmatian, M., Farhud, D.D. and Yunesian, M. (2008). Economic valuation of air pollution health impacts in the Tehran area, Iran. Iranian Journal of Public Health, 37(1): 20-30.

Landage, A. (2013). Low carbon building: An approach to sustainable development. Available at: http://dl.lib.mrt.ac.lk/bitstream/handle/123/8896/SBE-12-27. pdf? sequence $=1$.

Lehtinen, H., Saarentaus, A., Rouhiainen, J., Pitts, M. and Azapagic, A. (2011). A Review of LCA Methods and Tools and their Suitability for SMEs. Cheshire, UK: BIOCHEM.

United Nations Environment Programme (UNEP) (2009). Building and Climate Change. Paris: UNEP. Available at: http://www.greeningtheblue.org/sites/ default/files/Buildings\%20and\%20climate\%20change_0.pdf.

Nasrollahi, F. (2013). $\mathrm{CO}_{2}$ emission inventory in Iran. In Young Cities Research Paper Series. Vol. 2. Berlin: Universitätsverlag der TU Berlin.

Office of Energy and Power Affairs (2013). Iran's Energy Balance 2012. Tehran: Ministry of Power.

Reddy, B.V.V. (2009). Sustainable materials for low carbon buildings. International Journal of Low-Carbon Technologies, 4(3): 175-181. https://doi.org/10.1093/ ijlct/ctp025.

Sanders, N.R. and Wood, J.D. (2014). Foundation of Sustainable Business: Theory, Function and Strategy. New Jersey: John Wiley and Sons.

Simonen, K., Haselbach, L., Oneil, E., Cooper, J., Fish, D., Brown, B. and Thami, M. (2012). A Review of Resources on Life Cycle Assessment and Embodied Energy and Carbon in Building Materials. Washington: University of Washington (UW) and Washington State University (WSU). Available at: https://app.leg.wa.gov/ ReportsToTheLegislature/Home/GetPDF? fileName=LCA\%20for\%20WA\%20 Reference\%20Document_04759549-4b00-470e-a822-4a4b8678605a.pdf.

Unger, N., Beigl, P. and Wassermann, G. (2004). General requirements for LCA software tools. Proceedings of the International Environmental Modelling and Software Society (iEMSs) 2004 International Conference. Germany: University of Osnabrück. Available at: www.iemss.org/iemss2004/pdf/infotech/ ungegene.pdf.

Wang, Y., Wu, J. and Zhang, Q. (2016). A study on the BMl-based application in lowcarbon building evaluation system. International Journal of Structural and Civil Engineering Research, 5(2): 97-101. 